\title{
MAIN CHALLENGES FOR THE GREEK NATIONAL SECURITY AGAINST THE GEOPOLITICAL CHANGES IN THE BALKANS DURING THE PERIOD 1918-1923
}

\author{
J̨̨DRZEJ PASZKIEWICZ
}

\begin{abstract}
The aim of the article is to show the role of the Balkan states within the Greek foreign policy during the period 1918-1923, on the base of diplomatic correspondence and historiography. The consequences of the military conflict with Turkey (1918-1922) and the internal problems, constantly harassing the socio-political life of Greece, seriously weakened its ability to impact effectively on particular geopolitical problems in the Balkan region. The Greek regional policy could be achieved, completely or partially, only with close cooperation with the powers from outside. It was connected with such cases as the delimitation of the Albanian frontier or the solution of the Western Thrace question in 1920. On the other hand, the proceedings of the Greek diplomats were determined by the belief that due to the unresolved territorial and national controversies, especially in the issue of the Macedonian and Thracian lands, the particular Balkan states were dependent on each other on the international arena. That is why the Greek diplomacy started to apply the tactics of balance of power in the region, aiming at the creation of more or less stable bilateral political constructions with the Kingdom SCS (Yugoslavia) and Romania. Their aim was to ensure the advantage over the competitors on the Balkan arena, especially over Bulgarian and Turkish revisionist agendas.
\end{abstract}

STRESZCZENIE. Wyzwania dla bezpieczeństwa narodowego Grecji wobec zmian geopolitycznych na Batkanach po I wojnie światowej (1919-1923)

Celem artykułu jest ukazanie roli regionu bałkańskiego w greckiej politce zagranicznej w latach 1918-1923, na podstawie korespondencji dyplomatycznej i literatury przedmiotu. W omawianym okresie Grecja miała ograniczoną możliwość wpływania na geopolitykę regionu, ze względu na wojnę z Turcją (1918-1922) i rozliczne problemy wewnętrzne. Poszczególne cele terytorialne, np. kwestie delimitacji granicy albańskiej czy przynależności państwowej Tracji zachodniej, były realizowane w ścisłej współpracy z mocarstwami - sojusznikami z Ententy. Z drugiej strony, jak wynika np. z greckiej korespondencji dyplomatycznej, istniało przekonanie, że ze względu na istnienie wielu kontrowersji terytorialnych i narodowych, zwłaszcza dotyczących spraw macedońskich i trackich, poszczególne państwa bałkańskie były od siebie wzajemnie uzależnione na arenie międzynarodowej. Z tego względu wyzwaniem dla greckiej dyplomacji było utrzymanie równowagi sił w regionie poprzez stosowanie taktyki „przeciągania liny”. W szczególności starano się aranżować mniej lub bardziej stabilne konstrukcje polityczne z Królestwem SHS i Rumunią, nastawione na zdominowanie rewizjonistycznej Bułgarii i Turcji.

Author: Jędrzej Paszkiewicz, Uniwersytet im. Adama Mickiewicza, Wydział Historii, ul. Uniwersytetu Poznańskiego 7, 61-614 Poznań, Polska, prosinac@amu.edu.pl, ORCID iD: https://orcid.org/0000-0002-71159284

Keywords: Balkans, Greece, Bulgaria, Turkey, interwar period

Slowa kluczowe: Bałkany, Bułgaria, Turcja, okres międzywojenny

Balcanica Posnaniensia. Acta et studia, XXVI, Poznań 2019, Wydawnictwo Instytutu Historii UAM, pp. 193212, ISBN 978-83-66355-32-3, ISSN 0239-4278. English text with summaries in English and Polish.

doi.org/10.14746/bp.2019.26.11 
The period following the Great War (1914-1918), when the new international treaty system was in formation, presented a series of threats to Greece's position in the internal Balkan relations. The country sought to establish a comprehensive foreign affairs strategy when still engaged in armed conflict to expand its territorial gains in the Asian (Aegean) part of Turkey and faced with a grave crisis of the state power. These interconnected circumstances resulted in splitting this period into two distinct phases, influenced mainly by the frontline dynamics of the Asia Minor campaign. Phase one, lasting from 1919 until 1921, was the time of military success over the Turkish armed forces, when the internal Balkan affairs were not an immediate concern of the state. It was followed by phase two (1922-1923), when the limitation of the political aftermath following the defeat in the war against Turkey became the primary task of Greek diplomacy.

The political activity of Greece in that period was focused on securing its national interests in the context of the armed conflict in Minor Asia, which engaged almost all military capabilities of the country. The Greek army was involved in this war as an ally of the Entente, but it was becoming evident that Greece could not rely on the world powers' assistance due to a considerable conflict of interests. Consequently, from 1919 to 1921 the Greeks benefited from the supporting position of Great Britain, as their diplomatic and military activities in the Aegean region were regarded as an important element of establishing the British zone of influence over the eastern Mediterranean. The Greek foreign affairs policy of that time, concerned with creating a regional power in the Aegean, was much in favour among the British government. However, the turn of 1920 saw a shift in this position, when the parliamentary elections in Greece gave the power to the political circles supporting king Constantine II, who had been removed from the throne by the Entente three years prior to the event ${ }^{1}$. The external support for Greece's armed actions against Turkey was further weakened by the political changes in London (parliamentary elections) and the British and French attempts at the diplomatic resolution of the conflict in Turkey. These unfavourable conditions, resulting from the gradual loss of importance of Greece as a part of the British policy for the Mediterranean-Turkish region, corresponded strongly with the consolidation of the Turkish independence movement and the indifference to the Greek interests in the region on the part of France and Italy ${ }^{2}$.

The Balkans were considered a secondary, yet complicated, element of the game which Greece was forced to play while being involved in an armed conflict. In this context, the Greek geo-political strategy needed to take several interconnected circumstances into account. First, the need to bring stability to the political relations with

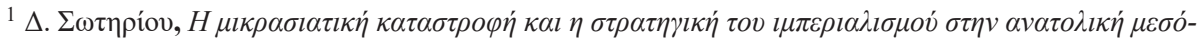

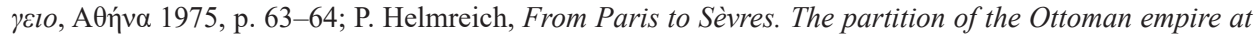
the peace conference of 1919-1920, Ohio 1974, p. 316.

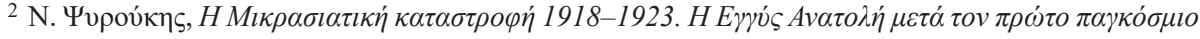
$\pi o ́ \lambda \varepsilon \mu о, \Lambda \varepsilon v \kappa o ́ \sigma 1 \alpha 2000$, p. 254. 
neighbouring Balkan countries, so that the main attention and resources could be directed to the decisive moves on the Turkish front; and second, the territorial discrepancies and border problems in the Balkans that were awaiting resolutions. These concerned the aftermath of war regarding the Thracian region, which had been claimed by Greece, Turkey and Bulgaria. Securing the political division on Macedonian land and establishing the post-war borders of Albania were separate issues. None of these could have been postponed until the Turkish war was over. They needed to be resolved simultaneously, taking into account the peculiarities of the Balkan geopolitics as well as the interests of the world powers. Another important goal was to ensure the territorial integrity of Greece itself as well as to consolidate its real control over the northern territories. Although Macedonia and Epirus were incorporated a year before the outbreak of the Great War (1913), the integration of them remained an enormous challenge on both the administrative and the economic level. The ethno-nationalist politics was becoming increasingly important in this period, as the presence of non-Greek national and ethnic minorities, which formed a significant part of the northern population, was regarded a threat to the country's security and its territorial integrity. The minority population was considered a natural base for the development of separatist or irredentist movements. There was a pressure towards either displacement or assimilation (hellenisation) of minorities.

According to the Greek reason of state, the crucial goal in the 1919-1923 period was the peaceful settlement of the relations with the neighbouring countries, by means of multilateral treaties, in order to consolidate the new borders of the country and minimise the threat of foreign interventions in Greece's internal affairs. In the short-term perspective the goal was to achieve such a state of international relations, whereby the negative consequences of Greece's engagement in the Turkish war would be limited.

The long-term goal on the other hand, included reaching a balance of power which would secure the treaty system in south-east Europe established over the 1919-1923 period on the basis of the series of peace treaties (with Germany, Austria, Hungary and Bulgaria and Turkey) ${ }^{3}$ and secondly, within the League of Nations' system. Without doubt, Greece's geo-political environment at that time clearly imposed the necessity to consolidate the peace agreements in the Balkans and to neutralise any revisionist activities. The overall efficiency of the Greek policy regarding the Balkans was dependent on the level of co-relation between the national interests pursued by the particular countries in the region and the interests of the world powers. Taking advantage of the areas where the Greek reason of state converged with the approach of other Balkan countries towards the new international order was also considered an important factor.

\footnotetext{
3 The peace treaties that ended the First World War in Europe: Versailles: June 28, 1919 (the Allies and Germany); Saint-Germain-en-Laye: September 10, 1919 (the Allies and Austria), Neuilly: November 27, 1919 (the Allies and Bulgaria); Trianon: June 4, 1920 (the Allies and Hungary); Sevres: August 10, 1920 and Lausanne: July 24, 1923 (the Allies and Turkey).
} 
The Balkan region was an area of co-existence of several countries with differing reasons of state and discrepant geopolitical interests. Even though the national interests of these countries were often conflicted, they had none the less much in common. As an example, their rates of socio-political and economic transformation processes were quite similar. They also shared many solutions within their political systems and faced similar problems in their internal affairs. Their preferences with regard to the national security were just similar, concentrating on the marginalisation of the ethnic minorities' influence on the overall situation of the country by means of their elimination or assimilation. Another characteristic shared by all the countries in the region was the insufficient level of integration of certain parts of their territories and populations into the state structures, not to mention their significant setbacks in the civil and economic development, as compared to the countries of the West. Finally, their current international affairs policies were commonly and significantly conditioned by certain past events.

The analysis of the Balkan internal relations at that time displays two cardinal and quite contradictory tendencies. On the one hand, the nations of the region pursued various forms of local cooperation in order to improve their own level of security. On the other hand, the particular interests were invariably concentrated on the strengthening of the national identity, country-wide unification and the greatest possible territorial gains at the expense of the neighbours ${ }^{4}$. As a result of these contradictions, the social and political transformations which accompanied the evolution of the Balkan states' system show a characteristic persistence of traditional ethnic and religious antagonisms, despite the shifting international configurations ${ }^{5}$.

As this was so, the Greek-Bulgarian relations were mainly influenced by the territorial disputes regarding the multi-ethnic lands of Macedonia and Thrace. Both sides supported their claims with regard to ethnic, lingual and religious affinity with the population of the contested areas. They both widely used the heritage narrative. Bulgaria would claim the right to the lands which formed a part of the Bulgarian state during the Middle Ages, while Greece would reach back to the heritage of the Argead dynasty and the Byzantine Empire, associated with the tradtition of th Greek ethnos. The sources of the political strife between Greece and Bulgaria (and between Bulgaria and Serbia) should be located at the turn of the 19th century, when the Bulgarian nationalism had risen to struggle for the influence over Turkish European territories, spreading the nationalist propaganda among the Slavic ethnic groups. The slogan of unifying all „Bulgarians in their „motherland” remained in strength despite the defeat suffered by Bulgaria in the Great War. The loss of the western Thrace to Greece in 1920 was a severe blow, as the area had been under the administrative and military control of

\footnotetext{
${ }^{5}$ R. Peckham, National histories, natural states: nationalism and the politics of place in Greece, London 2001, p. 62-76, 147-152.
} p. 110.

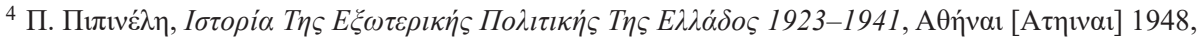


Bulgaria during the 1914-1918 period. The Greeks held this decision of the Entente powers as a natural result of their country's engagement in the fight against Bulgaria during the war. Obviously the Bulgarian side regarded the Greek presence in western Thrace as a temporary occupation, aimed at the elimination of the Slavic ethnos in the region or its disconnection from the Bulgarian heritage. Bulgaria made repeated diplomatic attempts to influence the world powers to repeal their decision, exercising the claims to Bulgaria's ecomonic access to the Aegean sea, as included in the Treaty of Neuilly-sur-Seine ${ }^{6}$.

Bulgarian policy was revisionist in nature. It was supported with the arguments of repressions suffered by Bulgarian Slavs not only in Greece, but also in Romania and the Yugoslav state. In such a state of affairs, the main goal of Bulgarian foreign policy was to achieve a position equal to its neighbours on the international level, by means of repealing the conditions of the Treaty of Neuilly-sur-Seine regarding the military limitations and the country borders. However, Bulgaria remained isolated on the international arena due to the incessant territorial and national struggles with all its neighbouring countries. The neutralisation of the Bulgarian revisionism regarding the Balkans determined the overall international relations in the region. This also mobilised Greece to co-operate politically with the other beneficiaries of the Versailles Treaty, despite the growing differences among them.

The historical vicissitudes had little influence on the Greek-Serbian relations, even though the two countries vied for the position of the political and spiritual centre of the Balkan Orthodox world, following the fall of the oecumenical patriarchate at the turn of the 19th century. Despite this, the lack of major territorial struggles opened the possibilities for political and military cooperation during the Balkan Wars (19121913) and the Great War. Late 19th century saw certain Serbian thinkers and politicians create a vision of a joint Serbian-Greek state, with ideological roots in the shortlived empire of Stefan Uroš IV Dušan, which existed between 1346 and 1355. Such ideas could exist in the public sphere due to the rising threat of the Bulgarian nationalism regarded in both Serbia and Greece as equally dangerous as the nationalist politics of Turkey ${ }^{7}$.

The first two decades of the 20th century saw the establishment of the political framework for Greek-Serbian cooperation. Initially, this alliance was aimed primarily against the Turkish presence in the Balkans. Later however, Bulgaria became its main target. The shared military victory over the Ottoman Turkey and then Bulgaria over the course of the two Balkan Wars cemented the Greek and Serbian common interests.

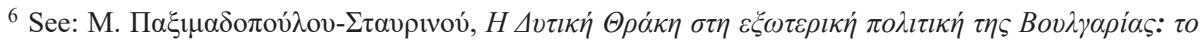

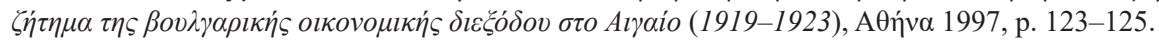

${ }^{7}$ И. Пржић, Мећународно-правна кроника, Београд 1922, р. 359.
} 
It resulted in combined arms operations against the Bulgarians on the Macedonian Front during the period $1917-1918^{8}$.

Contrarily, the Greek conduct towards the neighbouring southern Slavic countries was heavily influenced by the anxiety that the Serbs could compete with, or even pose a threat to the Greek interests in the Balkans. According to the conservative opinions of Stefanos Dragoumis (1846-1923), the Greeks and the Serbs were the two local powers in the Balkans. They were both based on differing civil and religious foundations. In order to prevent a direct clash with the Serbian nationalism, which (exactly like its Greek counterpart, the Megali Idea) relied profoundly on historical reasoning, S. Dragoumis suggested to only co-operate with Serbia in current political struggles regarding the fight against Turkey and Bulgaria. He made suggestions to approach Serbs with limited trust, due to the fact that their territorial ambitions involved all southern Slavic nations. The Serbian expansion could potentially encompass the regions populated by the Greeks. S. Dragoumis went as far as to argue that a safer solution for Greece could lie in an agreement with Turkey, in order to halt any potential invasion of the Slavic nationalism, from either Serbia or Bulgaria ${ }^{9}$.

The proclamation of the Kingdom of Serbs Croats and Slovenes (Kingdom SCS) in December 1918 met with ambivalent reactions in Greece. The Yugoslav state was regarded in Athens as an avatar of the so-called Greater Serbia, which in its propaganda referred to the legacy of the mediaeval Nemanjić dynasty. When Aleksander Karadjordjević, as the regent, proclaimed the Kingdom in 1918, one of the Athenian newspapers related the event with a fear that the next target of the Serbian nationalism would be the remaining Balkan areas with any percentage of Slavic population, irrespective of their national or cultural identity. The territorial ambitions of the newlyformed state were portrayed as a potential threat, as its future was deemed dependent on the continued expansion to the south-east. ${ }^{10}$. On the other hand, the representatives of the Greek government declared that the creation of the Kingdom SCS was politically satisfying. This event was associated with the broader process of the struggle for independence by the southern Slavic nations and the establishment of a new balance of power in south-east Europe, which was in accord with the forthcoming treaty conference in Paris ${ }^{11}$. As argued by Eleftherios Venizelos, the creation of the Kingdom SCS allowed a realistic hope for the consolidation of the peaceful state of balance between

${ }^{8}$ H. Gardikas Katsiadakis, Greece and the Balkan imbroglio. Greek foreign policy, 1911-1913,

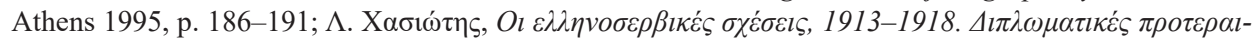

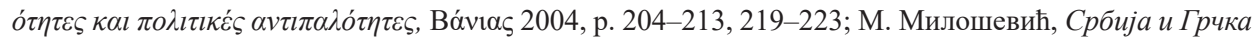
1914-1918. Из историје дипломатских односа, Зајечар 1997, p. 199-258.

${ }^{9}$ Y. Konstantinova, The place and role of Stephanos Dragoumis in the Greek political elite in the late 19th and the early 20th c., „Balkan Studies” 2008, no 2, p. 71-73.

10 Archivio Storico Diplomatico (ASD), Affari Politici 1919-1930: Grecia, 1214/1919 (28.01.1919);

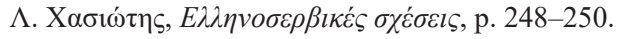

11 N. Petsalis-Diomidis, Greece at the Paris Peace Conference (1919), Thessaloniki 1978, p. 67-68,

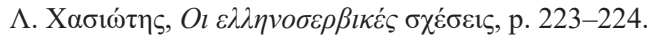


the particular Balkan countries. The political and territorial changes in Romania were commented upon in a similar manner on the Greek side.

Without doubt, the international Greek activity at that time was overshadowed by the concern regarding a potential Slavic Alliance in the Balkans. As a result, the Greek public opinion developed increasing anti-Yugoslav and anti-Serbian attitudes. Any criticism towards Greece, appearing mainly in the Belgrade press, was observed from Athens with growing anxiety. The accusations against Greece focused on its cunctative position during the Great War, that the Greeks only joined the armed struggle on the side of the Entente at the end of the conflict. Other opinions suggested that Greece would expect support from the Kingdom SCS in its own territorial claims, without offering anything in return ${ }^{12}$.

In the Balkan context, the conflict between Greece and Turkey primarily affected the resolutions regarding the Thracian land. During the Great War eastern Thrace belonged to Turkey and the western part to Bulgaria. In the aftermath the land came under the occupation of the allied forces. (1918-1923) ${ }^{13}$. From the Greek perspective, controlling this area was an element of the regional power strategy. The Thracian issue was incorporated into the political programme aimed at creation of the Greater Greece on the lands previously under the Turkish rule. This state would encompass all lands historically inhabited by the Greek population, even if it didn't constitute the majority in a given region. The pursuit of this goal was conceived in Greece under the guidelines of the nationalist ideology, which determined Greece's diplomatic course of action in the period prior to the Treaty of Lausanne (1923) ${ }^{14}$.

On the other hand, the ambitions of the Yugoslav government also involved the creation of a local power, reflecting the national ideology formulated and pursued beforehand by the Kingdom of Serbia ${ }^{15}$. However, the opportunities to efficiently exercise the Serbian interests in the Balkan arena were quite limited. One of the obstacles were internal struggles, caused by the Serbian unitarisation attempts conflicting with

12 The Romanian diplomacy did not play as active role in the Balkans as the Kingdom SCS. The Romanian authorities were focused on searching the allies against the Soviet revisionism and the infiltration of the communism. In the Balkans Romania was interested in cooperation against Bulgaria and Bulgzarian revisionism. Romanian representatives supported international order in the region, giving priority to Yugoslav (Serbian) interests. On the other hand, Romania presented a very critical attitude considering the plans of Yugoslav-Bulgarian rapprochement, supported by the French diplomacy; А. Кузманова, От юой до крайова. Въпросът за Южна Добруджа в международните отношения 1919-1940, София 1989, р. 135-137.

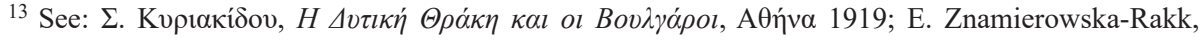
Sprawa Tracji zachodniej w polityce butgarskiej (1919-1947), Warszawa 1991.

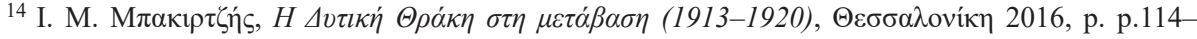
117.

15 Britanci o Kraljevini Jugoslaviji. Godišnji izveštaji Britanskog poslanstva u Beogradu 1921-1938, ed. Ž. Avramovski, Zagreb 1995, vol. 1, p. 162. 
the aspirations of the other nations within the joint state organism ${ }^{16}$. Yugoslav politics relied upon the support of France and the allied countries of the Little Entente (1920/1921), Czechslovakia and Romania. This foundation was deemed hardly sufficient. Even the influential world power, with its interest-bound allies, would not be in position to protect the Kingdom SCS against the threats from within the Balkans. The allies were quite willing to co-operate in order to counter the Bulgarian revisionist attempts, but their interests differed with regard to the issue of the Italian expansion. Meanwhile, it was Italy that posed the greatest threat to the Yugoslav position in the Balkans, issuing territorial claims to the Adriatic coast and broadening its influence over Albania and Bulgaria.

The growing Italian activity in the Balkan region, obvious during the time of the Great War, was a significant threat to the Greek national interests as well. Italy not only denied the sovereignty of the Kingdom SCS, but also became the unofficial advocate for the Bulgarian policy during the treaty negotiations. Moreover, Italian diplomacy supported the Albanian interests during the negotiations regarding the latter country's borders. Naturally, the government in Athens was well aware that the primary target of Italian attacks was not Greece, but the Kingdom SCS. However, there were reasons to suspect that any political activity in the Balkans against Greece would be supported by the Italians, due to their hostile attitude towards the Greek armed actions in Anatolia ${ }^{17}$. Moreover, the Greeks were conscious that the Italian claims to the parts of the east Adriatic coast would strictly limit the possibilities for Kingdom SCS to use the harbours of that area for military or economic purposes. In such circumstances it was expected that the Kingdom would be forced to divert their expansion into the south-east. These predictions proved not far from reality. When on November 12, 1920 the Kingdom SCS made agreements with Italy regarding the future of Rijeka/Fiume and Zadar (the Treaty of Rapallo), the pressure from the Serbian political and economic circles on the regulations regarding the free-trade zone in the Thessaloniki harbour was immediately increased ${ }^{18}$.

The analysis of the diplomatic correspondence indicates that Greece found itself in an awkward position due to the Italian-Yugoslav conflict (1919-1920), regarding

16 Ф. Тајзен, Југословенски проблем. Студија о балканској политици, Београд 1929, р. 78; Љ. Петровић, Југословенска држава и друитво у периодици 1920-1941, Београд 2000, p. 174.

${ }^{17}$ F. Grassi, L'Italia e la questione turca (1919-1923). Opinione pubblica e politica estera, Torino 1996, p. 18-19; T. Wituch, Od Trypolisu do Lozanny. Polityka Włoch wobec Turcji i Bliskiego Wschodu w latach 1912-1922, Warszawa 1986, p. 48.

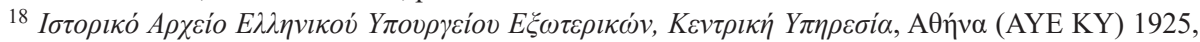
A/5/III (31.12.1924; 17.01.1925); see: J. Paszkiewicz, Jugosławia w polityce Włoch, Poznań 2004, p. 116-120. From the Greek point of view, the signing of the Italian-Yugoslav treaty, in January 1924, showed, that the concept of the Yugoslav expansion towards the south of the Balkan was strengthened. There were rumours that during secret negotiations Italy was ready to support Serbian aspirations towards Thessaloniki and preliminarily accepted the idea if division of Albania. The Information was denied by the sides of the treaty, but in the Greek opinion Italy wanted to see more active engagement of Yugoslavia in the Aegean area instead of Adriatic sea. 
the international recognition of the Kingdom SCS. According to the Prime Minister, E. Venizelos, the Yugoslav issue required great caution and preferably the suspension of any independent actions until the most notable world powers show their hand. The Greek prime minister argued that Greece should avoid any conflict with Italy, and thus remain neutral in the struggles around the Adriatic sea. E. Venizelos instructed the vice-minister of foreign affairs Alexandros Diomidis, that the Greek diplomatic service should be rather reserved in any discussions regarding the recognition of the Kingdom SCS and avoid placing Greece in a position which could provoke the Italian retaliation ${ }^{19}$. The Greeks were planning to reach their own, separate compromise with Italy and solve the conflicting interests regarding the northern Epirus and the Aegean region as soon as possible ${ }^{20}$. They declared that the agreement with Italy signed on the 29th of July 1919 (the Venizelos-Tittoni agreement) was not meant to threaten the interests of Yugoslavia and that it created possibilities to disrupt the Italian-Bulgarian liaison ${ }^{21}$. However, the agreement failed to fulfil its purpose, never having come into being. It was revoked by the new Italian government in July 1919. Never the less, the fact that it had been signed had a detrimental effect on the GreekYugoslav relations ${ }^{22}$.

Despite the above, the prospects of Greek-Yugoslav diplomatic cooperation were brighter with regard to the conditions of the treaty between Bulgaria and Entente, which were negotiated in the same year. The representatives of both Greece and the Kingdom SCS worked in unison on the forum of the treaty conference, focusing on their common goals ${ }^{23}$. In their opinion the disarmament process of the Bulgarian military forces was facing multiple obstacles. Consequently, the Yugoslav diplomacy appealed to the Entente headquarters in Istanbul to join the allied forces with the Greek troops in an operation to take control over Strumica, a city in Vardar Macedonia, which remained under occupation of the Bulgarian army. The leaders of both delegations issued a note to the French minister of foreign affairs Georges Clemenceau, to address the threat posed to their countries by the armed bands of marauders stationed on the Bulgarian side of the border. On his own account E. Venizelos suggested in

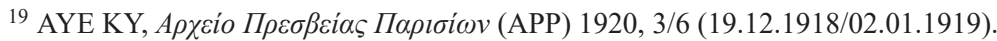

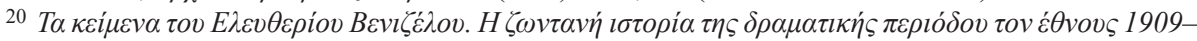

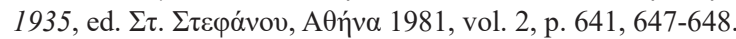

${ }^{21}$ Archivio Centrale dello Stato, Roma (ACS), Archivio F.S. Nitti 21/65/2 (Asia Minore) (29.07.1919); On the basis of the Tittoni-Venizelos treaty, the both sides agreed the issue of the Dodecanese archipelago and the North Epirus. Greece recognized Italian interests in the central part of Albania and promised to protect Italian affairs in the Smirne region, which was under Greek administration; F.L. Grassi, L'Italia e la questione turca (1919-1923). Opinione pubblica e politica estera, Torino 1996, p. 66-68.

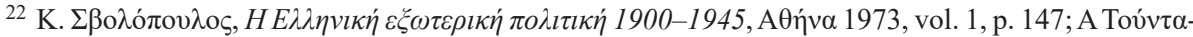

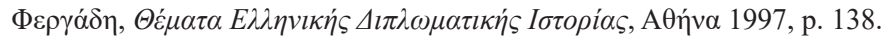

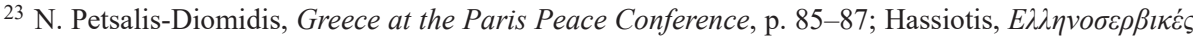

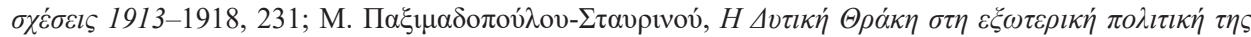
Boviyapias p. 27-28; Athanasios Loupas, From Paris to Lausanne: aspects of Greek-Yugoslav relations during the first interwar years (1919-1923), Balcanica 2016, vol. 47, p. 267. 
1919 , that this threat could be efficiently neutralised by a combined operation in south Bulgaria involving Serbian, Greek and Romanian forces ${ }^{24}$. However, the prime minister shortly withdrew from the plan of a commom military action against Bulgaria. He concluded that such a course of action could lead to another war, which would unnecessarily engage the Greek forces in the Balkans. Instead, he advocated for a diplomatic action to increase the Serbian and Romanian political and military pressure on the government in Sofia and force Bulgaria to exercise all conditions of the armistice and the following peace treaty ${ }^{25}$.

The Greek-Yugoslav cooperation achieved tangible results, forcing Bulgaria to withdraw its garrison from Strumica and western Thrace on the 17th of September 1919, before the conclusion of the treaty negotiations. Following the Treaty of Neuillysur-Seine, the city and the provinces of Bosilegrad, Tsribrod were taken over by the Kingdom SCS. The same agreement introduced a joint allied administration in western Thrace, which severed Bulgaria's direct access to the Aegean Sea. Within half a year the international San Remo conference (April 25, 1920) handed over the political and military control over western Thrace to the Greek administration. Such an outcome opened the possibilities to integrate this region with Greece, although it did also result in the aggravated resistance from the local Slavic and Turkish population. All movements which could undermine the Greek rule in this area were supported by both Bulgarian and Turkish governments, which in turn resulted in a sense of common threat perceived in both Athens and Belgrade. From the point of view of the Kingdom SCS, any Turkish-Bulgarian cooperation on the Thracian issue, which also involved political circles supporting the Macedonian movement, would eventually turn against the Yugoslav control over Vardar Macedonia. The Belgrade press at the time implied that the Turkish agents were in action among the Muslims in Macedonia and the Sanjak of Novi Pazar. Unconfirmed news surfaced concerning the increased activity of Albanian nationalists in Macedonia and Kosovo. Allegedly, they were interested in cooperation with the guerrilla forces led by Djafer Tayyar, fighting the Greeks in western Thrace ${ }^{26}$.

According to the Greek standpoint, the threat posed by the Bulgarian revisionism served as a paradoxically stabilising factor in the region's political relations. This problem mobilised the countries involved in territorial disputes with Bulgaria to solve all their bilateral relations on a daily basis. For this reason, Athens received with anxiety the news from Belgrade or Sofia, regarding the attempts to settle the matters between the Kingdom SCS and Bulgaria. To the Greeks, any positive solutions to these issues could be followed by a rapprochement between the two southern Slavic states. Even though the threat of a South Slavic union was hardly realistic, any information

${ }^{24}$ D. Todorović, Jugoslavija i balkanske države, 1918-1923, Beograd 1979, p. 36-38.

${ }^{25}$ N. Petsalis-Diomidis, Greece at the Paris Peace Conference, p. 267.

${ }^{26}$ National Archives, London, Foreign Office (NA FO), 371/6096, Greece. Annual report 1920, p. 12. 
on the growing affinity between Bulgaria and Yugoslavia would be uneasily received in Greece. Such a process could lessen the impact of the so-called Bulgarian issue on the Balkan geopolitics, and thus had a negative influence on the security of Greece's northern border ${ }^{27}$.

In fact, during the rule of the Bulgarian National Union (1919-1923), the country experimented with a certain pro-Yugoslav approach, in order to overcome its political isolation and improve the chances of gaining the economic access to the Aegean Sea. Prime Minister Aleksandar Stamboliyski set as his cardinal goal the disruption of the Serbian-Greek-Romanian cooperation, which dated back to the period of the Balkan Wars and was intended to hinder the Bulgarian territorial programme. Overcoming the disputes regarding both land and ethnicity had been an important theme since the beginning of the 1920s. It should also be mentioned that the vision of Yugoslav-Bulgarian rapprochement was explicitly supported by France. This set of circumstances resulted in the anxiety on the Greek side that the country could face the international isolation when the Minor Asia campaign required the maximum possible deployment of military, financial and political resources. Eventually, the reluctant attitudes of both the influential political circles and the Bulgarian public opinion rendered impossible to solve the disputes between Bulgaria and the Kingdom SCS. Ironically, the right-wing military coup d'état on the 8th of June 1923, which brought an end to the leftist government in Bulgaria, was a relief not only to Greece but also to Romania. On the other hand, the right-wing government of Aleksandar Tsankov took advantage of the mild tone of the diplomatic reports on the coup to increase the number of troops. It violated the conditions of the Neuilly-sur-Seine Treaty and justified this action with the alleged need to defend the country against the Bolshevik infiltrators. The Bulgarian government circles discussed the rapprochement possibilities with Romania, due to the need to halt the progress of communist revolution in southeast Europe. Cooperation with Turkey was also taken into consideration. Even though Turkey was regarded as the vanguard of the Soviet influence on the region, it could still be a potential ally to Bulgaria against the Greek nationalism ${ }^{28}$.

It was impossible to form any cooperation between Turkey and Kingdom SCS against the Greek interests in Thrace. In May 1921 Turkey submitted the proposal of a political and military alliance, in which the Turkish army would engage the Greek troops in eastern Thrace, while the Yugoslav task force would capture the city of Thessaloniki. The Turkish diplomacy expected the world powers not to react to this violation of the peace order, as they were quite absorbed by the issues regarding Germany. The fact that the support for Greek interests from London and Paris was being withdrawn at that time, after the reinstatement of King Constantine II, presented

27 AYE KY, 1923, 6/3/1/1 (06.04.1923).

${ }^{28}$ NA FO, $286 / 861$ (13.06.1923); idem, 286/841 (06.07.1923); S. Evans, The slow rapprochement. Britain and Turkey in the age of Kemal Atatürk 1919-1938, London 1982, p. 86-87. 
an opportunity for Turkey ${ }^{29}$. The Yugoslav Prime Minister Nikola Pašić, however, declined the proposal. He supposed that the Turks intended not only to weaken the position of Greece, but also to consolidate political contacts with the Muslim population in Vardar Macedonia, Bosnia and Sanjak. The prime minister's categoric refusal was also influenced by the reports on contacts between Kemalist circles and the Bulgarian government as well as Turkey's support for the activity of the Thracian movement, which cooperated with its Macedonian counterpart ${ }^{30}$.

The press comments in Belgrade suggested that the return of Turkey to the arena of Balkan politics would result in strengthening of the position of revisionist countries, which aimed to disrupt the post-war status quo in the region. The „Politika” daily suspected that Turkey would become another link in the Italian, Hungarian and Bulgarian chain of affinity, which was set against the interests of the Kingdom SCS. This threat was becoming even more visible with the growth of the Fascist movement in Italy, which presented a hostile approach to the treaty arrangements in the Balkans.

The Yugoslav government declared neutrality regarding the Greek-Turkish conflict. In the diplomatic exchange with Greece was asserted, that the conditions of a new alliance could be hardly negotiated during the time when one side was engaged in an armed conflict. A similar position was assumed by the Romanian side towards the attempts to settle the conditions of the Romanian-Greek neutrality agreement. Both issues were close scrutinized by a personal representative of King Constantine II in Belgrade and Bucharest Victoras Dousmanis in February 1922 $2^{31}$. The aim of his mission was to assess the opportunity to include Greece into the Yugoslav-Romanian defence agreement. Moreover, the Greek diplomat was gathering information on the Yugoslav position regarding the prolongation of the Serbian-Greek Alliance signed originally in 1913. At that time Prime Minister N. Pašić replied to V. Dousmanis that the Kingdom SCS considered itself a guardian of the Treaty of Neuilly-sur-Seine. On the other hand, the Romanian prime minister Take Ionescu, was willing to consider the inclusion of Greece into the system of Little Entente, however not prior to the settlement on the conditions of the new alliance with Yugoslavia ${ }^{32}$.

${ }^{29}$ Arhiv Jugoslavije, Beograd (AJ), 370/I/3 (08.05.1921; 14.05.1921).

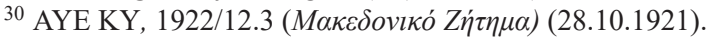

${ }^{31}$ AJ, 395/7/28 (21.03.1921). According to German sources, the distrust towards V. Dousmanis shown by the Yugoslav side was a serious obstacle to the extension of the treaty of alliance (Little Entente) which was to expire the following year; A. Loupas, From Paris to Lausanne, p. 273-274.

32 NA FO, 371/7603, Greece. Annual report 1921, p. 28. The first proposals regarding Greece's access to the Czechoslovak-Yugoslav-Romanian alliance were submitted by E. Venizelos in 1920, after the signature of the Sèvres treaty. His initiative, however, met with the reluctant position on the Czechoslovakian Prime Minister Edvard Beneš, who considered Bulgaria to be a potentially more valuable asset to the alliance. On the other hand, E. Venizelos gained the support by the Romanian minister of foreign affairs Take Ionescu. The latter was convinced that the alliance should be extended to include the countries in the belt running from the Baltic Sea to Thessaloniki. The Kingdom SCS did not openly oppose Venizelos' propo- 
The dispute regarding the potential access of Greece to the Little Entente resurfaced during the celebrations of the marriage between Aleksandar Karadjordjević and the Romanian princess Maria Hohenzollern in June 1922. The two-strong delegation from Athens comprised of the ministers of foreign affairs and the military, Georgios Baltatzis and Nikolaos Theotokis was tasked with the assessment of the approach of the two Balkan countries involved to the ongoing events concerning the war in Minor Asia ${ }^{33}$. According to the report by the minister of foreign affairs, the sides discussed multiple issues: the prolongation of the Greek-Serbian alliance, the status of the Yugoslav commercial zone in Thessaloniki and the potential joint operation of the Greek, Yugoslav and Romanian armed forces against the marauders striking from Bulgarian territory. However, from the Yugoslav-Romanian viewpoint, the cooperation with Greece could only be considered in the case of Bulgarian revisionism. Broadening the range of the joint action was impossible due to the war in Minor Asia. The Greek delegation accomplished the primary goal which involved the prevention of the threats to the security of Greece's northern reaches, the Aegean Macedonia and western Thrace. However, establishing common strategic objectives for the cooperation with the other most important countries of the region proved impossible. The only common ground that Greece could count upon was the need to counter the Bulgarian revisionist attempts.

The Greek influence on the internal Balkan relations became even more unpredictable as a result of the defeat in Asia Minor and the anti-monarchist coup on the 11th of September 1922. A republican-inclined junta took over the government (colonels Nikolaos Plastiras, Stylianos Gonatas, captain Dimitrios Phokas) and the foreign affairs fell exclusively into the hands of E. Venizelos. In his opinion, the international circumstances at that time made any plans to incorporate eastern Thrace definitively futile. He asserted that it was necessary to gain support from Belgrade and Bucharest for the Greek position in the treaty negotiations with Turkey. However, the Greek politicians were anxious about the ambiguous attitude of the Yugoslav government towards the Turkish presence in the Balkans. As was recorded in the diplomatic correspondence, the prime minister N. Pašić was against shifting the Turkish border further than the Gallipoli peninsula, but on the other hand, the foreign affairs minister of that time, Momčilo Ninčić, was in favour of the French position, that Turkey should take over the eastern part of Thrace. Eventually, the opinion which prevailed in Belgrade was, that if Turkey was not allowed into eastern Thrace, then Bulgaria was likely to seize the initiative regarding this region ${ }^{34}$. For Bulgaria, the Greek defeat in Minor Asia opened the opportunities to re-address the issues concerning the Bulgarian interests in western Thrace on the diplomatic arena. What the government in Sofia counted

sal, yet preferred to divide the matters of Balkan geo-politics from the issues regarding the central-eastern Europe; see: M. Vanku, Mala Antanta 1920-1938, Titovo Užice 1969, p. 16.

${ }_{33}$ Britanci o Kraljevini Jugoslaviji, vol. 1, p. 94.

${ }^{34}$ D. Todorović, Jugoslavija i balkanske države, p. 177-178. 
on, was that under sufficient political pressure Greece would accept a creation of a territorial corridor, which would provide Bulgaria with the access to the Aegean Sea.

This issue was the reason behind the visit by A. Stamboliyski in Belgrade in October 1922. This was the first occasion since the end of the Great War on which the prime minister of Bulgaria paid an official visit to the Yugoslav capital. Greece was of the opinion that A. Stamboliyski was seeking the support of the Kingdom SCS for his position in the forthcoming treaty conference. He didn't mention the territorial claims regarding Vardar Macedonia. Furthermore, he declared that the government in Sofia would take action to prevent the assaults from the Macedonian bands. The Greek observers to this visit assessed that A. Stamboliyski lacked the political credibility to the Yugoslav side. His government was never able to influence effectively the Macedonian activists to any significant degree. Secondly, his postulates regarding the creation of the autonomous zone in western Thrace were deemed in Belgrade a threat with regard to the situation in Macedonia. From the Yugoslav point of view, such a solution would be tantamount to a revision of the treaty of Neuilly-sur-Seine. In fact, during the peace negotiations at Lausanne, M. Ninčić stated that the autonomy formula should not be applied to politically contested territories in the Balkans. Thus, he supported the Greek stance in this regard ${ }^{35}$.

Having closely scrutinised the ambiguous diplomatic moves of Yugoslavia towards Bulgaria, Greece insisted on some sort of settlement to the growing contradictions. With this in mind, the Greek minister of foreign affairs Nikolaos Politis visited Belgrade in early November 1922. His attention focused on improving the cooperation against the Macedonian movement. As was reported in the Greek press, N. Politis met with a warm welcome from N. Pašić and M. Ninčić, who unanimously assured him of the infrangibility of the alliance between their two countries. However, the prolongation of the agreement remained open to discussion. Moreover, it was linked to the postulate of establishing a Yugoslav commercial zone in Thessaloniki. For the Greeks this resulted in a weakened position to negotiate, creating a field where they would be compelled to yield to certain demands. To address these issues, N. Politis offered to negotiate a bilateral transit contract, including the operation of a commercial zone in the Thessaloniki harbour, and drawing on the previous agreements from 1914. He was also forced to answer undesirable questions regarding the future fate of the Slavic population in western parts of Aegean Macedonia, an ethnic group considered as a Serbian minority by the Yugoslav side. Answering the enunciations found in the Belgrade press, N. Politis denied that the Greek government was planning to displace these people in order to prepare space for the growing number of Greek refugees from Asia Minor. He also refuted the press comments on anti-Slavic sentiments among the Greek population in Macedonia, allegedly provoked by the Greek migrants from the Serbian part of Macedonia. The Greeks assessed that the issues of ethnicity and nationality surfaced as a consequence of the dispute regarding the commercial

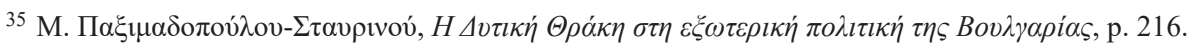


zone in Thessaloniki. They could possibly be used to undermine the Greek position, or removed altogether from the discourse, depending on the course of the negotiations. The Greek government did not recognise the existence of a Serbian minority and was reluctant to negotiate the question. Greece saw it as a tactical ploy of the Yugoslav side in an attempt to force Greeks into concessions regarding the commercial dispute. N. Politis was convinced that the Kingdom SCS had no real intention of raising another difficulty in the already politically sensitive Macedonian issue. He considered the comments in Yugoslav press, with regard to the alleged displacement of Greek Slavs, to be an attempt to interfere with Greece's internal affairs, yet without any real influence on the bilateral relations ${ }^{36}$.

The Greek minister emphasised the mutual need of the two countries to cooperate over the differences, due to the threats posed by Bulgaria. Answering the question of Bulgarian economic access to the Aegean Sea, he stated that Greece would respect the international law regulations, based on the Danube shipping convention, with regard to the river navigation on Marica (Evros) and the Karağaç-Alexandroupoli (Dedeağaç) railway line. N. Politis did not fail to mention the events in the Bulgarian city of Nevrokop where the opposing factions of IMRO had broken into street fighting in October 1922. According to the Greek minister, such an incident implied the friendly attitude of the Bulgarian administration towards the Macedonian terrorist movement. He followed to propose a joint trilateral diplomatic intervention in this case. The Yugoslav side, however, was not interested in initiating any joint actions against Bulgaria. Addressing the issue of Bulgaria's access to the Aegean Sea, M. Ninčić suggested not to assume any common standpoint. Regarding the Greek minister's expectations that the Kingdom SCS could oblige itself to support Greece in case of a Turkish or Bulgarian invasion, $M$. Ninčić declared that he would not tolerate any forms of aggression from Bulgaria. Despite that, he did not mention any potential military aid to Greece in the case of war. Above all, the Kingdom SCS insisted on the Greek side to resolve the issues concerning the Thessaloniki harbour. It was obvious that the Yugoslav side could gain considerably more in this field than was originally anticipated, by taking advantage of Greece's political isolation ${ }^{37}$.

${ }^{36}$ AYE KY, 1922, 6.7/1/1 (04/17.11.1922). M. Ninčić reassured N. Politis that in his opinion the issues of the Slavic minority should be settled by a bilateral agreement, without the intervention of the League of Nations. He claimed that the government in Belgrade felt obliged on racial grounds to be concerned about the fate of the Slavic population in the western part of Greek Macedonia; AYE KY, 1922/17/5 $(23.10 / 05.11 .1922)$.

37 One of the most difficult tasks that the Revolutionary Committee had been charged with was to form a capable fighting force from the remnants of the Army of Asia and restore order and discipline in the army. This mission was carried out successfully by general Theodoros Panghalos. Very soon Greece disposed of an army of more than 100000 soldiers capable of undertaking a new offensive on Eastern Thrace.

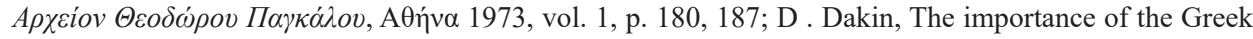

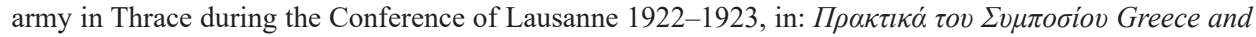
Great Britain during World War I, Thessaloniki 1985, p. 221. 
In November 1922 the plenipotentiary minister of the Kingdom SCS in Athens Živojin Balugdžić, submitted a memorandum to the Greek minister of finance Andreas Hadjikyriakos, linking the question of the free harbour zone with the necessity to create a joint administration over the railway stations in Thessaloniki and Gevgelija and install Yugoslav customs officers in these places. The Greek government agreed to separate a section of the harbour for transit purposes, declining the postulate of introducing the Yugoslav regulations and customs control into the Greek territory. Instead it was suggested that a private consortium should be appointed to administer the free zone on behalf of Yugoslavia. The Yugoslav side expressed their discontent with Greece's reply. In an interview for the Belgrade daily "Politika" Ž. Balugdžić emphasised the fact that the city of Thessaloniki had been captured during the first Balkan War as a result of a joint operation of the allied forces. Thus, the Greeks should find themselves obliged to return this certain political debt to their Serbian partner by allowing the free access to the harbour. According to the minister, the concessions regarding the Yugoslav export and transit were the necessary condition of any further cooperation ${ }^{38}$. The Kingdom SCS was blocked by Italy to use the Adriatic coast for commercial reasons and it had to take strong pressures on Athens regarding the Thessaloniki harbour ${ }^{39}$.

In the meantime, a series of negotiations between Yugoslavia and Bulgaria were initiated in early March in Niš and widely publicised by the propaganda. The primary goal was the neutralisation of Macedonian gangs assaulting the Serbian Macedonia. However, the signing of the bilateral agreement on the 23rd of March 1923 was received in Greece with a considerable level of anxiety. It was suspected that the proBulgarian course of action prevailed in Belgrade at the expense of the support for the Greek interests in Thrace ${ }^{40}$. When the Greek foreign affairs minister Apostolos Alexandris arrived in Belgrade, in mid-April 1923, and requested the insight into the implementation of the agreement, the Yugoslav side assured him that its intention was to secure the country border rather than establishing any sort of far-reaching political affinity with Bulgaria. Furthermore, it was indicated the potential joint diplomatic action towards Bulgaria was possible, if the government of A. Stamboliyski offer military aid to Turkey in any conflict with Greece. N. Pašić also reassured A. Alexandris that the Kingdom SCS would support the Greek stance in claiming the reparations from Turkey. The Yugoslav side was also against any political or territorial shifts in western Thrace, which could be against the interests of the Athens ${ }^{41}$.

All these declarations were expected to be "sealed" by the agreement regarding the Yugoslav commercial zone in Thessaloniki. The tempo of the negotiations grew,

38 D. Bakić, The Port of Salonica in Yugoslav Foreign Policy 1919-1941, „Balcanica” 2012, vol. 43, p. $197-198$.

39 J. Paszkiewicz, Grecja a bezpieczeństwo międzynarodowe na Bałkanach w latach 1923-1936, p. 49.

${ }^{40}$ AYE KY, 1923, 6/3/1/1 (06.04.1923); Britanci o Kraljevini Jugoslaviji, vol. 1, p. 172-173.

${ }^{41}$ A. Loupas, From Paris to Lausanne, p. 279. 
becoming finalised in a bilateral transit convention signed in Belgrade on May 10, 1923. The agreement was connected to the previous arrangements in this issue from 1914. The zone was considered the Greek territory, however its daily functioning was based on the Yugoslav legal and customs system. The personnel was comprised of Yugoslav citizens, delegated to Thessaloniki by the Kingdom's administration ${ }^{42}$.

Such settlements meant that Greece had yielded to nearly all Yugoslav demands, as to the conditions regarding the management of the commercial zone and the Thessaloniki-Gevgelija railway connection. Given the circumstances at that time, it was of utmost importance to improve the Greek bargaining position for the treaty negotiations with Turkey. Despite this, when the negotiations were interrupted in May 1923, the government in Belgrade refused to issue a common Greek-YugoslavRomanian démarche to Sofia with regard to the Bulgarian support to the Turkish interests in Thrace. It was decided at that time that a joint diplomatic action could work as an encouragement to Greece to engage in military action against Bulgaria, thus placing The Kingdom SCS in an embarrassing position to both neighbouring countries ${ }^{43}$.

The Greek-Turkish agreement, reached during the treaty negotiations in Lausanne in 1923, was in accord with the presumptions of the Yugoslav and Romanian governments. First of all, the renewal of the armed conflict between Greece and Turkey, this time in the Balkan region, was avoided. Such a development could lead to the depletion of Greece's previous territorial gains and aggravate the international isolation of the country. It was significant that the Greek-Turkish agreement was reached by the political circles which had quite a realistic view over the international situation of that time. Contrary to the Greek public opinion that Turkey should be forced into concessions, the government decided to settle peacefully all bilateral disputes. The opinion prevailed that the compromise with Turkey should serve primarily to bar any further proceedings by Bulgaria regarding the Aegean Sea and western Thrace. In fact, when Greece conceded the city of Karağaç to Turkey, the Bulgarian territorial claims immediately involved parts of Turkish territory. As the Greeks had hoped, this was tantamount to a foreclosure of any meaningful Bulgarian-Turkish cooperation against Greece ${ }^{44}$.

The 1919-1923 period was a breaking point for the Greek approach to the geopolitical situation of their country, as understood in the national categories. The de-

${ }^{42}$ AJ, 379/1 (1919-1925), Конвенција и протоколи о српској слободној зони у Солуну, p. 3-6; Г.

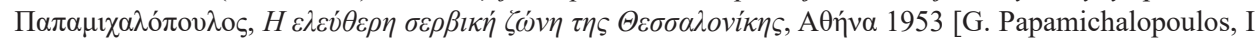

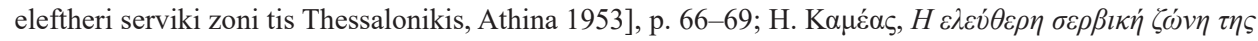

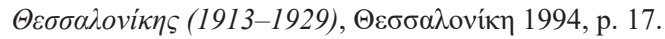

43 A. Loupas, From Paris to Lausanne, p. 280.

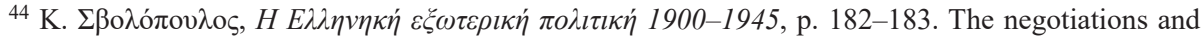
the following signing of the Treaty of Lausanne on 24 July 1923 opened a new phase in the bilateral Greek-Turkish relations. The border between the two countries had been traced definitively, which initiated a gradual shift in the priorities of the Greek national security policies. The Treaty of Lausanne resulted in the overall bilateral relations being less influenced by the issues of nationality, ethnicity and religion. At the turn of the 1920s it was deemed the foundation for the settlement of the mutual relationships and the departure point for the future political and military cooperation. 
feat suffered by the Greek military in Minor Asia forced Greece to withdraw from the plans to become a regional power in the Aegean area, a somewhat abstract concept inspired by the Megali Idea. The immediate agenda shifted to the organisation of the country's territory in such a way, as to secure the national interests to a highest possible degree on the relatively ethnically homogeneous land. As a result, the diplomatic actions were followed by the policies regarding the population and ethnicity, aimed at the displacement of communities of non-Greek ethnic and cultural characteristics.

Without doubt, the issues of territorial integrity and border security became the priorities to the Greek geopolitical thinking regarding the Balkans over the course of year 1922. The stabilisation of the Greek position in the Balkans was a prerequisite to any proceedings with Turkey and the Mediterranean countries. The Balkans, in contrast to the Mediterranean region, allowed more space for diplomatic manoeuvre. This was the area where the pressure from the world powers was less constricting and the relative assets of the involved countries were comparable. All of them faced similar challenges regarding the security of their territories and borders. On the other hand, it should not be forgotten that at that time the Greek government found itself in a situation of a permanent political crisis as well as an internal, social and economic collapse of the country, resulting from the military disaster suffered in Minor Asia. Meanwhile, the Kingdom SCS and Romania, despite their own internal struggles were gradually strengthening their international positions in Europe. The two countries were seen as the guardians do the post-Versailles order and benefited from French support, while Greece's international credibility was on the decline due to the ongoing political turmoil. Greece was reluctant to make major concessions to the Kingdom SCS, although the government was well aware that affinity with the Kingdom was the country's only chance to efficiently challenge Bulgaria in the Balkan arena. Such a lack of geo-political alternative very much constricted the manoeuvre possibilities of the Greek diplomacy with regard to the regional issues until the end of 1920s.

This period 1918-1923 in the history of Greek diplomacy could be described as a time of fire-fighting actions, where the flames caused by the engagement in the war in Minor Asia erupted time and again. This conflict diverted Greece's attention away from the issues of fundamental importance to the post-Great War arrangements in the Balkans. The Greek diplomacy only participated in these matters to a limited degree, technically focusing on the sole purpose of securing the background for the actions against the Bulgarian revisionist practice. The 1920s were a time when the Greek political elite viewed the Balkan geo-politics piecemeal as a series of separate threats to be neutralised au courant, not solved in a systematic manner. The visions of cooperation with Romania and the Kingdom SCS were based merely on the common anxiety regarding their territorial security. Stimuli were lacking to promote a more far-reaching system of cooperation, e.g. in the field of commerce or communication. The bilateral relations were plagued by precariousness, or even angst that the common ground provided by the imminent threat from Bulgaria could vanish if any potential southernSlavic alliance came into being. 


\section{BIBLIOGRAPHY}

\section{Archival sources:}

Archivio Centrale dello Stato, Roma (ACS) Archivio F.S. Nitti

Archivio Storico Diplomatico, Roma (ASD) Affari Politici 1919-1930: Grecia

Arhiv Jugoslavije, Beograd (AJ)

370: Poslanstvo Kraljevine Jugoslavije u Turskoj, Carigrad, Ankara

379: Poslanstvo Kraljevine Jugoslavije u Grčkoj, Atina

395: Poslanstvo Kraljevine Jugoslavije u Rumuniji, Bukurešt

National Archives, London, Foreign Office, London (NA FO)

286: Consular archives, 1923-1929

371: Political departments: General correspondence, 1906-1966

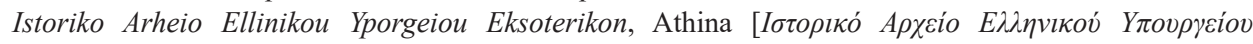

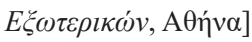

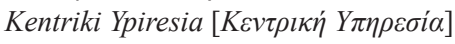

\section{Publications:}

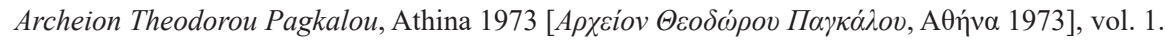

Bakić D., The Port of Salonica in Yugoslav Foreign Policy 1919-1941, „Balcanica” 2012, vol. 43, p. 191219.

Britanci o Kraljevini Jugoslaviji. Godišnji izveštaji Britanskog poslanstva u Beogradu 1921-1938, ed. Ž. Avramovski, Zagreb 1995, vol. 1.

Chasiotis L., Oi ellinoservikes sheseis, 1913-1918. Diplomatikes proteraiotites kai politikes antipalotites,

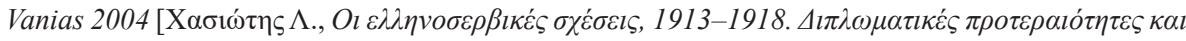

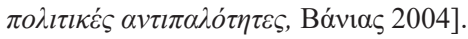

Dakin D., The importance of the Greek army in Thrace during the Conference of Lausanne 1922-1923,

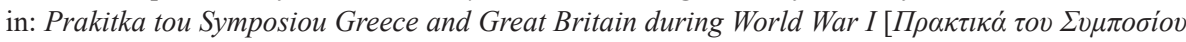
Greece and Great Britain during World War I], Thessaloniki 1985, p. 210-232.

Evans S., The slow rapprochement. Britain and Turkey in the age of Kemal Atatürk 1919-1938, London 1982.

Gardikas Katsiadakis H. , Greece and the Balkan imbroglio. Greek foreign policy, 1911-1913, Athens 1995.

Grassi F.L., L'Italia e la questione turca (1919-1923). Opinione pubblica e politica estera, Torino 1996.

Helmreich P., From Paris to Sèvres. The partition of the Ottoman empire at the peace conference of 1919 1920, Ohio 1974.

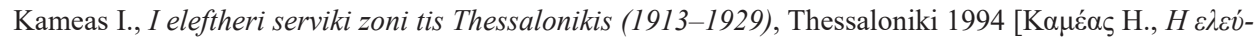

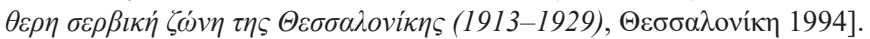

Konstantinova Y., The place and role of Stephanos Dragoumis in the Greek political elite in the late 19th and the early 20th c., „Balkan Studies” 2008, no 2, p. 55-81.

Kuzmanova A., Od njoj do krajova. V'pros't za Južna Dobroudža w meždunarodnite otnošenija, Sofija 1989 [Кузманова А., От њой до крайова. Въпросът за Южна Добруджа в международните отношения 1919-1940, София 1989].

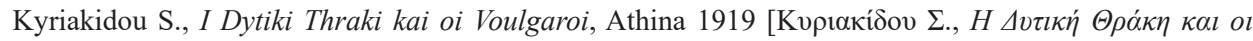

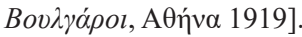

Loupas A., From Paris to Lausanne: aspects of Greek-Yugoslav relations during the first interwar years (1919-1923), Balcanica 2016, vol. 47, p. 263-284.

Milošević M., Srbija i Grčka 1914-1918. Iz istorije diplomatskih odnosa, Zaječar 1997 [Милошевић М., Србија и Грчка 1914-1918. Из историје дипломатских односа, Зајечар 1997]. 


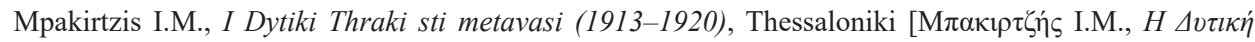

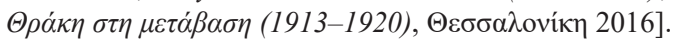

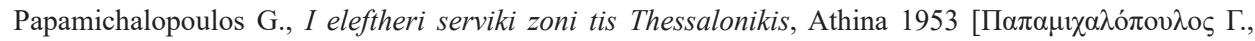

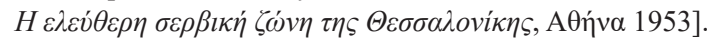

Paszkiewicz J., Jugostawia w polityce Włoch, Poznań 2004.

Paszkiewicz J., Grecja a bezpieczeństwo międzynarodowe na Bałkanach w latach 1923-1936, Poznań 2012.

Paksimadopoulou-Stavrinou M., I Dytiki Thraki sti eksoteriki politiki tis Voulgarias: to zitima tis voul-

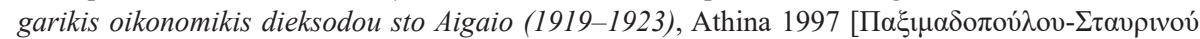

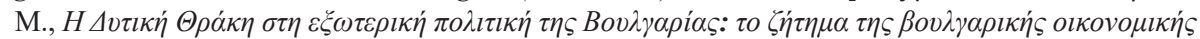

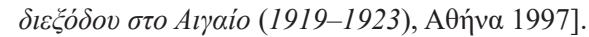

Peckham R., National histories, natural states: nationalism and the politics of place in Greece, London 2001.

Petrović Lj., Jugoslavoenska država i društvo u periodici 1920-1941, Beograd 2000 [Петровић Љ., Југословенска држава и друштво у периодиии 1920-1941, Београд 2000].

Petsalis-Diomidis N., Greece at the Paris Peace Conference (1919), Thessaloniki 1978.

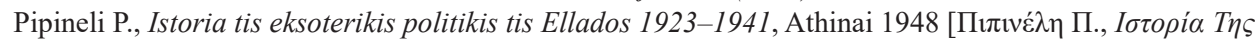

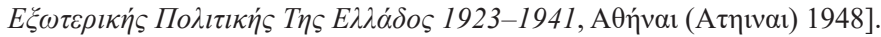

Pržić I., Međunarodno-pravna kronika, Beograd 1922 [Пржић И., Мећународно-правна кроника, Београд 1922].

Psyroukis N., I Mikrasiatiki katastrofi 1918-1923. I Engys Anatoli meta ton proto pagkosmio polemo,

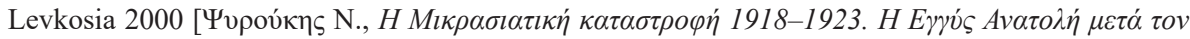

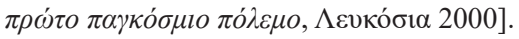

Sotiriou D., I mikrasiatiki katastrofi kai i stratigiki tou imperialismou stin anatoliki mesogeio, Athina

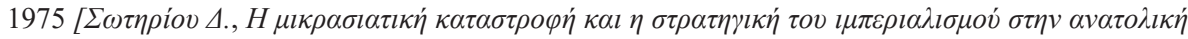

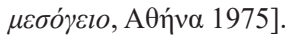

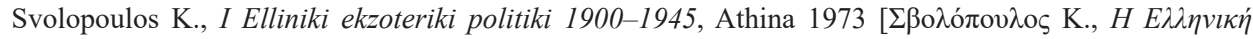

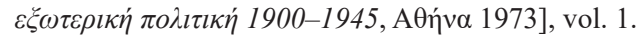

Ta keimena tou Eleftheriou Venizelou. I zontani istoria tis dramatikis periodou ton ethnous 1909-1935, ed.

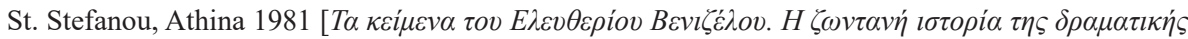

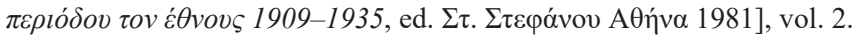

Tajzen F., Jugoslovenski problem. Studija o balkanskoj politici, Beograd 1929 [Тајзен Ф., Југословенски проблем. Студија о балканској политици, Београд 1929].

Todorović D., Jugoslavija i balkanske države, 1918-1923, Beograd 1979.

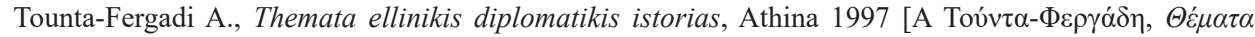

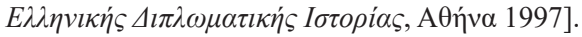

Vanku M., Mala Antanta 1920-1938, Titovo Užice 1969.

Wituch T., Od Trypolisu do Lozanny. Polityka Wloch wobec Turcji i Bliskiego Wschodu w latach 19121922, Warszawa 1986.

Znamierowska-Rakk E., Sprawa Tracji zachodniej w polityce butgarskiej (1919-1947), Warszawa 1991. 